\title{
Negative Marketing in Political Campaigns and Its Effect on the Voting Decision of the Indian Millennial
}

\author{
Nicolas HAMELIN ${ }^{*}$, Kabir MANDREKAR ${ }^{* *}$, Talha HARCAR ${ }^{* * *}$
}

Received: October 17, 2018

Revised: February 12, 2019

Accepted: March 1, 2019.

\begin{abstract}
In an unprecedented event, the current ruling party of India - the BJP - won the UP election in 2017 after 15 years of domination by the Congress. In 2016, when all the pollsters and pundits statistically analyzed the ongoing election for US Presidency and predicted a Hillary Clinton victory, they all got it wrong. While the results seem miraculous in the eyes of the experts, the careful strategy executed by the political campaigners of all these parties involved a unique process of market segmentation, but more importantly, an effective manipulation of social media that was strong enough to change voting behavior. In this research we conducted a study that mimicked a social media political campaign of three Indian political parties and measured the effect of positive and negative fake news on the voting intention of the Indian millennial. We submitted the participants to a series or positive or negative news - all fabricated about 3 main Indian political figures, Rahul Gandhi, Arvind Kejriwal and Narendra Modi, while monitoring their subconscious emotional state. The results were stunning. We found that a mere 60 seconds was enough to heighten the participant emotional state and significantly alter participant perception and ratings about these politicians.
\end{abstract}

Keywords: Negative Marketing, Political Campaigns, Voting Decision, Indian Millennial

JEL Code Classification: M1, M3

UDC: 339.138

DOI: https://doi.org/10.17015/ejbe.2019.023.01

\footnotetext{
* Dr. Nicolas Hamelin, S P Jain School of Global Management, Dubai · Mumbai · Singapore · Sydney, Australia. E-mail: nicolas.hamelin@spjain.edu.au

** Kabir Mandrekar, S P Jain School of Global Management, Dubai · Mumbai · Singapore · Sydney, Australia. E-mail: kabir.mandrekar@gmail.com

${ }^{* * *}$ Corresponding Author. Talha Harcar, Pennsylvania State University at Beaver, USA. E-mail: tdh13 $@$ @su.edu
}

Copyright (C), 2019 Ala-Too International University. 


\section{Introduction}

There are few theories, such as the directional theory of electoral choice, proximity model and the spatial theory which analyze choices in elections (Yuksel, Civan \& Gundogan, 2011). Negative campaigning has always been a popular tool of marketing amongst the political parties. It dates as far back as 1828, with the fight for US Presidency between General Andrew Jackson and the eventual president - John Quincy Adams. The 'mudslinging' as it is widely known has taken place in the form of running advertisements to attack the opposition's personality, record or opinion or flat out character assassination. Negative advertisements were classified into two broad types - attack ads and contrast ads. Attack ads did not have any positive content. They only contained negative content about the opposition that exploited the fears that voters had about certain pertinent issues. Contrast ads, on the other hand, were a juxtaposition of the positive content about the candidate and the negative content of the opponent. (Johnson-Cartee \& Copeland, 2013). The attack ads have proven to have more potential to shape the minds of the voters with regards to their view of the opposition. Both kinds of ads have been transmitted to the public through print and Television media. It is only off-late that the internet has played a major role in political communications.

Social Media made its way into the political campaigning in the 2008 elections. The 2008 elections were known in the mass media as the 'Facebook Elections'. A research by Pew Research found that $67 \%$ of American citizen get at least some news on social media, this number climb to $74 \%$ for the Nonwhites and the less educated a 10-points percentage increase since 2016 (Bialik \& Matsa, 2017). This was also the first time that more than half of the voter population used to internet to access the political process during the election. Out of these online users, $60 \%$ accessed the internet for political or campaign related news; $38 \%$ engaged with others in politics -related conversation; $59 \%$ of internet users.

Millennials are people born between the years 1980 and 2000. According to a UN Report, India has the world's largest youth population of 356 million (19-39-yearold) and by 2020 India is set to become the world's youngest country with $64 \%$ of its population in the working age group. Millennials spend one in every four minutes online on a social networking site. They spend up to $70 \%$ of their time on social media. $50 \%$ of Indian Millennials watch at one video every day. Millennials are set to be the social influencers of the future. The voting behavior of the Indian Millennial involves the following factors: negative news on social media, beliefs, evaluations, attitudes and voting decisions.

This study investigates the effect of negative news on social media on the beliefs of the individual. With attributes of fear and anger as well as evaluations of the voters which make about the candidates and how the beliefs and evaluations affect the attitude of the voter. 
Negative Marketing in Political Campaigns and Its Effect on the Voting Decision of the ...

\section{Literature Review}

\subsection{Big-Seed Marketing}

The big seed marketing model was first introduced by Watts, Peretti and Frumin (2007). In this model the power of traditional advertising is combined with the extra strength delivered by viral dissemination. Big Seed marketing is a typical viralmarketing model based on model from virology describing the spread of infectious disease. The spread begins with a seed of people who spread a message to their group of friends, who will in turn share / transmit the same message to their respective friends and so on. When a message is received by one individual, the reproduction rate or " $\mathrm{R}$ " is the number of new individuals to which the message is being transmitted. If $\mathrm{R}$ is greater than 1 , every individual who gets the message will, on average, spread it to more than one extra individual, leading an exponential spread of the message. This is not unlike an epidemic as described by virologist. If the reproduction rate is less than one, the outbreak will gradually retreat. By differentiation, viral messages with an $\mathrm{R}$ of under 1 are for the most part considered disappointments. That is on account of simply viral battles, similar to disease outbreaks, normally begin with few seed cases and rapidly burn themselves out unless their R exceeds the epidemic threshold, or tipping point, of 1 .

\subsection{Theories of ICT's and its Effect}

The part of information and communication technologies (ICT) has turned out to be progressively significant in contemporary social and political life. With respect to this, the going with mediated groups, networks, and organizational models, the way that creating communication frameworks affect public discourse is of vital importance. Besides, the conceivable outcomes of joint effort and open-source information have added to more prominent human productivity and potential. Habermas' talks on communication technologies concentrate on their negative effect on the public circle and participatory democracy. Habermas fights that this domain has been colonized as connections are progressively mediated by money and power, and that settled in political gatherings and premium gatherings now substitute for participatory democracy. He likewise guarantees that with the expanding power of media corporations in public life, people have turned out to be passive consumers of merchandise, administrations, political organization, and display. The outcome is a decrease in democracy, individuality, and freedom. In spite of the fact that he is hopeful about the likelihood of the renewal of the public circle - one that grasps democracy in view of a political group and an activist public circle that can collectively characterize its political will and execute it in light of normal interests - his hypothesis holds back before surveying how mechanical and media advances may convey this to realization.

Literature across the disciplines of sociology, anthropology, and communication studies has begun to acknowledge how new ICTs are revolutionizing the way collective political and social actions are organized, though scholars debate the 
impact of these new media with the potential of expanding the notion of public sphere through SNS. While there is agreement that SNS's dramatically expanded access to politically relevant information and offer citizens new possibilities for learning, resources, and action, it is largely based on the media form and integration. Many have noted specifically how these affect the way that volunteers are amassed, funds are raised, and messages honed and delivered. Some argue that it allows for a more informed citizenry and novel forms of activism in that there are multiple producers, distributors, and consumers of information. Similarly, scholars have noted the shift from the unidirectional flow of information toward new forms of media that provide Peer-to-Peer (P2P) sharing and horizontal forms of communication. Castell's approach to the media and the public sphere reframes the discussion in terms of the centrality of the network of information, going beyond Haberma's original conceptualization.

\section{History of Marketing in Political Campaign and Social Media}

Political marketing is the procedure by which political candidates and thoughts are guided at the voters with a specific end goal to fulfill their political needs and in this manner pick up their support for the applicant and thoughts being referred to. A superficial examination between marketing of goods and services, and marketing of political candidates would promptly point up no less than one normal idea advancement. Obviously, there is very broad utilization of media by the merchant and the possibility for the reasons for advising, reminding, and in addition changing attitudes and conduct. Conceivably, such an examination would likewise show that both marketing of goods and services, and marketing of political candidates use comparable apparatuses, for example, statistical surveying, and different statistical and computer techniques in concentrate the market.

The communication processes involved in the pre-social media era were largely TV, Radio and Print. Traditionally TV was the main media to influence voters' evaluation of a candidate. Extensive research has been conducted mostly in the US showing that the positive or negative message will effectively change voters 'voting intention. Candidate-positive or opponent-negative ads tend to create positive opinions among the electorate about their own candidacy or to depreciate the candidacy of their opponents. Abundant researches have shown that viewers' evaluations and ratings of candidates will improve significantly when ads focus on the positive aspect of a candidate (Tedesco \& Kaid, 2003; West, 1993; Kaid, Fernandes \& Painter, 2011). On the other hand, negative ads have proven to be efficient at lowering viewers' valuations of the targeted candidate (Kaid, Fernandes, \& Painter, 2011).

Although these focuses are basically correct, they indicate just a couple of the similitudes amongst marketing and political marketing. In 1996, political campaigning using cyberspace became a growing norm as many candidates created basic and simple websites that provided campaign materials electronically which 
would have typically been printed otherwise. By 2000, candidates expanded Web pages by urging viewers to make donations. However, clearly it was in 2004 that the Internet turned into a fundamental segment of political crusading as natives were progressively exploiting new ICTs to pick up learning of the hopefuls and take an interest in their political battles. Additionally, there was a move in the direction of more noteworthy national to-applicant and resident to-native intuitiveness through websites, online exchange discussions, and different ICTs. Amid the 2004 presidential race $37 \%$ of all Americans, and $61 \%$ of ones who utilized the Internet to get political news and data, talked about the competitors, volunteer, or offer commitments to applicants (Rainie et al., 2005).

The Facebook election was the entry of social media into political campaigning. Campaigning on Facebook was de-facto the entry of social media into the political campaigning arena. While the element of negative marketing remained constant, the effect was accelerated thanks to the social medium. The communication processes involved in the pre-social media era were largely TV, Radio and Print. And through these processes political marketers were able to get their message out to a large number of voters, but in the traditional sense that is all the advertisement would be able to achieve. Social media, however, gave rise to a concept called "big seed" marketing, which turned out to be greatly beneficial to the political marketers. While the element of negative marketing remained constant, the effect was accelerated thanks to the social medium.

The productivity and budgetary advantages of gathering pledges online as far as overhead cost and depending on majority supporters in contrast with conventional raising support is basic. In average gathering pledges drives, a rate of the assets raised are utilized to take care of the expense of the occasion; supporters are required to make a base commitment and standard mail is sent to numerous nonsupporters of cast a wide net.

The principle web based main impetus behind Dean's system was the utilization of associate toper governmental issues through manual referral and computerized connecting advances. Maybe best was the utilization of Meetup.com (an Internet instrument that permits people to associate for all intents and purposes keeping in mind the end goal to discover individuals in their neighborhood groups).

\subsection{Donald Trump Campaign}

Trump team most successfully applied Watts's theory at scale during Trump campaign. Before the election, Trump had a massive seedbed of 19 million Twitter followers, 18 million Facebook fans, and nearly 5 million followers on Instagram to begin with (Bickart, Fournier \& Nisenholtz, 2017). Zhang et al (2017) developed the concept of amplification and showed how traditional media channels such as broadcast and cable network by reporting on a tweet or posting would amplified the messages by reaching to other millions of viewers, who would in turn share these messages. Trump in effect doubled his Twitter followers during the 
campaign and gained over $\$ 2$ billion in free air time (Bickart et al., 2017). The seedbed Trump relied on were the groups who rejected mainstream conservatism in the United States - the called the 'Alt - right'. A majority of Alt Rightists supported Donald Trump's bid for the presidency, not necessarily because they believe that Trump was one of them, but because they thought he could destabilize the Republican Party and sway political discussion to promote their own ideology (Lyons, 2017). On the subjects of white-supremacism, neo-Nazism, anti-Semitism and Islamophobia, the Alt-right would disseminate negative news through their syndicate and influence the general public. Small towns in remote countries like Macedonia would create fake websites with American-sounding domain names Kirby (2018). Negative content and 'fake -news' stories against the opposition would be created and disseminated on these websites. The prime motivation for them would be to earn revenue through the pay- per - click model of Facebook. The click of a USA user would be worth more than any other user and news regarding Donald Trump and Hillary Clinton generated the most amount of traffic. (Smith \& Banic, 2016). It was further seen that non - factual negative news with sensationalist headlines garnered the greatest number of shares and views. For example, a story that claimed Hillary Clinton will be indicted in 2017 for crimes related to her email scandal generated 140,000 shares, reactions and comments on Facebook (Silverman \& Alexander 2018).

\subsection{The Obama Campaign: Peer-to-Peer Networks and New Media}

Barack Obama and his team were the first to truly adopt social media as political marketing tool. Obama's team through use of social media embarked into recapturing the youth vote. Obama has been naming a pioneer. In 2008, Obama consummated and far outperformed Dean's creative utilization of the Internet and added SNS to join online correspondence with on-the-ground soliciting endeavors. Their effort was clearly successful as over $66 \%$ of voters aged under 30 voted for Obama who disseminated his messages majorly through Myspace and Facebook. On his Facebook profile, Obama designed all the information available to the public the medium of language in form that would seem appealing to the young voters. As a result, Obama had more than 2 million American supporters on Facebook, more than 112000 supporters on twitter. He uploaded more than 1800 videos on his YouTube channel which counted to more than 115000 subscribers. His channel attracted more than 90 million video views and 17 million channel visits (Harfoush, 2009). Eventually, the Obama group composed the crusade and activation of supporters more like a social development than a conventional political battle.

In 2008 as the Obama staff specifically targeted youth to not only vote, but more importantly, to participate in the campaign by serving as recruiters, fundraisers, mobilizers, and canvassers. By creating opportunities the campaign not only appealed to, but mobilized this demographic by using language they understood and in familiar territory via SNS's including Facebook, MySpace, Twitter. By 2008 the use of digital forms of technology was extensive in political campaigns. Blogs, 
Negative Marketing in Political Campaigns and Its Effect on the Voting Decision of the ...

social networks, text messaging, email lists, candidate's Web pages, social networking sites, and photo and video sharing sites were harnessed to reach, inform, and mobilize supporters. All candidates had Web strategies, Web teams, and multiple points of presence online, including Facebook, MySpace and YouTube to connect with potential voters (Hesseldahl McMillan \& Kharif, 2008). Seven of the sixteen candidates who ran for the presidency announced their candidacies on YouTube, and all opened YouTube Takaragawa accounts. In preparation for the election, YouTube created YouChoose, a section of the site devoted to the posting of videos from candidates in the form of speeches and ads (Rawlinson, 2008). However, Obama far surpassed all the other candidates in its novelty of these 2.0 tactics. Early in the campaign he hired Facebook co-founder Chris Hughes as part of its team, showing an understanding of the importance of SNS's and, more specifically, the demographics most actively using new media. More than $70 \%$ of Americans aged 18-34 have or use a Facebook or MySpace account according to a recent Harris poll (Harris Interactive 2010). The social networking site MySpace hosted online town halls with presidential candidates at various colleges and universities whereby members could watch the webcast and submit questions both in person and over the Web. It also launched a pre-primary straw poll that allowed MySpace users to vote on candidates, and its Impact channel housed all of the presidential candidates 'official MySpace pages. The Obama campaign, more than that of any other candidate, mastered the use of new digital networks to rework the relationship between citizens and candidates, recognizing that tapping into social circles of young people was critical for their participation in Obama's bid for presidency. For example, wired Obama voters were more than twice as likely to contribute money (fifteen versus six percent) and to sign up for campaign-related volunteer activities (eleven versus four percent) than offline supporters (Smith, 2009). Overall, three million donors made a total of $\$ 6.5$ million donations online, adding up to more than $\$ 500$ million, and of those, six million were in increments of $\$ 100$ or less. Seventy-four percent of 2.0 Obama supporters got political news and information online, and twenty-two percent of voters under the age of thirty said that they would not have been as involved in the campaign if not for the Internet.

\subsection{Narendra Modi's Army of Trolls}

Narendra Modi, the Prime Minister of India and the Bharatiya Janata Party - the ruling party of the Indian Government saw great potential in the manipulation of social media through big seed marketing. The BJP and Narendra Modi had been convinced that the English media were out to undermine him and thus it was important to have control over the messages disseminated to the voting public. Social media became a necessity. (Kapoor and Dwivedi, 2015). The BJP IT cell is headquartered in Delhi and they have a few key members that decide the hashtags for the day for twitter and which messages will trend. They send instructions to a large set of social media workers across the country made up of party volunteers 
assigned to the IT cell and paid workers about the tweet agenda. The BJP, when the verification restrictions were less stringent, had created a bank of a thousand twitter accounts on the names of party workers to be used when needed. The BJP uses them for their storms of synchronized tweeting. They also have chatbots controlled by the headquarters to control the dissemination of identical content at the same time. To the outside world they look like a real user. But in reality, they are algorithms acting in social media networks. The cell works through repetition and crowding of timelines with a set tweet. (Pal, Chandra \& Vydiswaran, 2016).

These same social media workers malign journalists that write or speak against Narendra Modi, they look to gain popularity by inciting communal hatred (Ohm, 2015). For example, a tweet by a popular social media cell worker of the BJP calling for the mass murder of Kashmiris was retweeted 1184 times and liked 1086 times. Soon after Aamir Khan, a popular Bollywood actor made public remarks about a growing intolerance in the country, the BJP IT cell orchestrated a social media campaign to uninstall the Snapdeal mobile application - that was endorsed by Aamir Khan. Soon after, Snapdeal announced the cancellation of its endorsement with Aamir Khan (Qadri \& Mufti, 2016). These are a few examples of how the social media cell of the BJP used negative news to generate popularity amongst voters. This strategy helped Narendra Modi win the 2014 elections.

\section{Research Design and Measurement}

\subsection{Autonomic Measures}

Self-report or surveys suffer from heavy bias, for example, the Theory of Social Desirability posit that interviewees will tend to avoid socially unacceptable responses or will tend to provide answers which he or she perceives to be matching the value system of the interviewer (Hamelin, El Moujaid and Taichon, 2017; Benstead, 2013). It was suggested that online questionnaire would lessen the impact of social desirability and that respondent would provide more truthful answer, but a recent research confirmed that the bias was identical online, offline and paper surveys. (Dodou \& de Winter, 2014). Autonomic measures are known to be more effective than self-reports as they often capture reactions that are beyond the conscious control of the individual (Lewiski el al. 2014). Many tools are used, but each has its own limitations. One of the tools used is the Facial Action Coding System (Ekman \& Friesen 1978; Ekman, Friesen \& Hager 2002). This tool is extensively used to portray visible movement of the facial muscles. However, it did not demonstrate high performance in measuring the emotional responses toward advertisements (Derbaix, 1995). Electroencephalography (EEG) is used as a physiological measurement tool, but it is only able to measure arousal, and not emotional valences (e.g. Cook et al. 2011). Another tool, called Facial Electromyography (EMG), has shown better results in capturing individuals' emotional valences. It can also be used in parallel with self-report measures (Lang 
et al. 1993). To use EMG, electrodes have to be placed on the individual's face. This is invasive and has lower ecological validity (Lewiski el al. 2014). Skin conductance is another autonomic measure and relies on the level of sweat secretion to capture nervous system activation (Poels \& Dewitte, 2006), and the higher the level of skin conductance, the higher the physiological arousal (Ravaja, 2004). However, both negative and positive stimuli lead to the same level of nervous system activation (Hopkins \& Fletcher, 1994). Last but not least, measuring heart rate is also considered an autonomic measure, but since it cannot be associated with a direct stimulus, it is necessary to use it with other complementing autonomic measures (Hopkins \& Fletcher, 1994).

\subsection{Testing the Impact of the Fake News: The experiment}

A total of 30 participants (17 male and 13 female) were submitted to a series of positive and negative news - all fabricated - about three key Indian political figures - Rahul Gandhi, Arvind Kejriwal and Narendra Modi were used during monitoring their subconscious emotional state. Nearly half (49\%) had the equivalent of junior high school qualifications, and $19 \%$ had senior high school diplomas (known locally as 0 - and A-level holders respectively). Some $13 \%$ possessed university degrees, and the remaining $19 \%$ had grade-school qualifications. Some $25 \%$ were in clerical, sales, and production positions, and $20 \%$ held supervisory and technical jobs. Only $10 \%$ were in the managerial and professional ranks, $30 \%$ in other occupations, and $8 \%$ were unemployed at the time of the study. In terms of annual income, the majority $(75 \%)$ earned $\$ 24,000$ or less. The total duration of the experiment was two weeks. The group of 30 was randomly divided into two batches. Group 1 was exposed to positive news slides (See Appendix Picture A1) during the first week while group 2 was exposed to negative news slides (See Appendix Picture A2). In the second week, group 1 was exposed to negative news slides while group 2 was exposed to positive news slides. The respondents were asked to provide and approval rating for all the three politicians before being exposed to the positive news slides. Once they did so, they would be shown a series of 12 slides that contained tweets by the politicians in contention and positive news around the world. 12 slides were divided equally between tweets from Rahul Gandhi, Arvind Kejriwal and Narendra Modi. Each slide was displayed for a total of five seconds before moving on to the next slide. The respondents were then asked to provide another approval rating of the politicians after being exposed to the news slides. While conducting the experiment, the participant's autonomic body reaction using galvanic skin response and the participant's facial expression were monitored. Emotions biometric platforms was used to measure changes in galvanic skin response as well as facial expression. Autonomic body reaction gives great insight on people's emotional state. Emotions influence both individual's attitudes and judgments, and subsequently the decision -making process.

In this experiment each slide was shown for only 5 seconds, with a total exposure of 60 seconds. In these few seconds, the respondents were unable to consciously 
critically analyze the data provided. In human decision making, stimuli are first processed by the emotion brain or the amygdala. Stimuli are first processed by the emotional brain or the amygdala. The amygdala complex has long been known as part of the neural network essential for emotion (Gallagher and Chiba, 1996). The information is then emotionally tagged "good", "bad" or "neutral" and transferred to other regions of brain. Since the amygdala has extensive reciprocal connections with many cortical regions, including perceptual pathways such as the primary visual cortex, the inferior temporal cortex- essential for vision, the prefrontal cortex, involved in attention / decision making and the hippocampus the memoryrelated regions an emotional response will modulate cognitive functions such as perception, attention, memory and decision-making. (Brosch et al., 2013). The emotional evaluation states that something positive or negative is happening to the subject and will have effect to sway a decision toward a more positive or more negative appraisal of the stimulus (Bechara, Damasio, \& Damasio, 2000).

\section{Research Results}

Table 1 shows the results of the experiment. For Rahul Gandhi although exposure to negative or positive news contributed to a lower or a higher rating respectively t-test value shows that this difference may not be statistically significant, (T-test value $>0.0 .5$ ). On the other hand for Arvind Kejriwal a significant increase in rating occurred after the respondents were subjected to positive news. In the case of Narendra Modi a significant decrease or increase in rating was observed after the participants were subjected to negative or positive news respectively.(t-test<0.05).

\section{Table 1. Participants Change in Rating After Being Exposed to 12 Slides Positive or Negative for 6 Second per Slides}

\begin{tabular}{lccccccccc}
\hline Politicians & \multicolumn{3}{c}{ Rahul Gandhi } & \multicolumn{3}{c}{ Arvind Kejriwal } & \multicolumn{2}{c}{ Narendra Modi } \\
\hline & Before & After & T-test & Before & After & T-test & Before & After & T-test \\
\hline Negative News & 1.6 & 1.57 & 0.37 & 2.2 & 2.0333 & 0.1156 & 3.9666 & 3.6333 & 0.0078 \\
\hline Positive News & 1.4333 & 1.5 & 0.2117 & 2.1666 & 2.5333 & 0.0014 & 3.8666 & 4.0333 & 0.0286 \\
\hline
\end{tabular}

A linear regression was run testing possible correlation between change in rating and galvanic skin response and facial expressions (Contempt, Attention and Engagement) (See Table 2). Appraisal change is the value of the variation in the approval rating of each politician before being exposed to the stimuli (positive or negative) and after being exposed to the stimuli. Negative values show that the approval rating was lower on average after being exposed to the stimuli than before being exposed. Positive values show that the approval rating was higher on average after being exposed to the stimuli than before being exposed. Change in Facial expression and galvanic skin response (GSR) - linked to our body sweat gland - were found to be statistically ( $p$. value $<0.05$ ) correlated to the participant evaluation of the politicians. For instance, in the case of positive news a lower level of contempt leads to an increase in appraisal rating. Similarly, when respondents were subjected to negative news, a high level of contempt leads to a decrease in a 
Negative Marketing in Political Campaigns and Its Effect on the Voting Decision of the ...

politician rating. The same negative correlation is reported with anger. A higher level of anger leads to a decrease in rating. Regarding galvanic skin response, strong variation in GSR will invariably lead to the participant lowering their rating after being exposed to negative news or increasing their rating after being exposed to positive news.

\section{Table 2. Linear Regression of Rating Change with Respect to Facial Expressions and Galvanic Skin Responses}

\begin{tabular}{llllll}
\hline $\begin{array}{l}\text { Facial Expression } \\
\text { / GSR }\end{array}$ & P. Value & Coefficient & $\begin{array}{l}\text { Appraisal } \\
\text { Change }\end{array}$ & News & Gender \\
\hline Contempt & 0.0299 & -0.82627 & 0.1282051 & Positive & Female \\
\hline GSR & 0.0082 & 0.06920 & 0.1282051 & Positive & Female \\
\hline Engagement & 0.0495 & -0.53285 & 0.2549019 & Positive & Males \\
\hline GSR & 0.0473 & 0.04097 & -0.1282051 & Negative & Males \\
\hline Attention & 0.0479 & -0.71737 & -0.1282051 & Negative & Males \\
\hline Contempt & 0.0291 & -1.7795 & 0.2 & Positive & Males \& Females \\
\hline Contempt & 0.027 & 0.85314 & -0.1777777 & Negative & Males \& Females \\
\hline Anger & 0.0086 & 3.5487 & -0.1777777 & Negative & Males \& Females \\
\hline
\end{tabular}

\section{Conclusions and Managerial Implications}

Each slide was shown for only 5 seconds, with a total exposure of 60 seconds. In this short span of time, the respondents were not able to consciously critically analyze the data provided. The data was processed by the emotional part of the brain or the amygdala whose role is to stick an emotional "tag" to the stimulus received. This emotional tag "good", "bad" or "neutral" sways the participant toward a more positive or more negative appraisal of the stimulus. A change in the facial expression and galvanic skin response (GSR) - linked to our body sweat gland - were found to be highly correlated participant evaluations of the politicians. For instance, the higher level of "contempt" recorded on the face of the participant, the more likely for the participant to attribute a lower rating score to all politician at the end of the test. Similarly, strong variation in GSR will invariably lead to the participant lowering their rating after being exposed to negative news or increasing their rating after being exposed to positive news. This research shows that a mere 60 seconds of fabricated news is enough to significantly influence our choice and perception. With Facebook soon exceed the 2 billion users, it is worrying what a few data miners and political marketing experts can do with an election and the future of millions of citizens.

Political campaigns the world over can use this body of knowledge to craft campaigns that suit their outcome. They can use the power of social media to spread their propaganda and while they pay attention to the arousal of key emotions in their political messages they have the power to manipulate the minds of their voters and influence their voting intention. 
This paper shows that confirmation bias reduces pandering, as it lowers the electoral "reward" for this behaviour by reducing the increase in the probability of being elected from pandering. As pandering generally has an ambiguous effect on voter welfare, it is possible that an increase in confirmation bias (parametrized by the probability of misreading policy choice, the signal about the benevolence of the politician) increases voter welfare. This baseline result on pandering is robust to a number of extensions of the model, but does not extend to the case where the incumbent can have three terms of office, or when payoffs are observable with a high probability.

\section{Research Limitations and Future Research Directions}

Traditional neuroscience research usually uses small sample sizes (10-20) owing to constraints of methods and expenses (Ansari \& Coch, 2006). However, Button et al. (2013) showed that small samples size is strongly undermining the reliability of research in neuroscience. With a sample size of 30 respondents this is potentially clearly the case here although no data points were excluded. To counter the effect of misinterpretation in P-value Hentschke and Stüttgen (2011) suggested the use of MES or Measures of Effect Size (MES) as a more reliable statistical tool. MES was not available in the analytical software employed for this study. However, Button et al. (2013) also posit that other sources of evidence would be necessary to alleviate the problematic of evidence resulting from small sample size studies. A higher sample size would be desirable to consolidate the findings of this study, yet it is also worth noticing that a vast amount of research on the impact of advertising on voting intention (Van Steenburg, 2015) support of the above findings.

\section{References}

Ansari, D. \& Coch, D. (2006). Bridges over troubled waters: Education and cognitive neuroscience. Trends in cognitive sciences, 10(4), 146-151. https://doi.org/10.1016/i.tics.2006.02.007

Bechara, A., Damasio, H., \& Damasio, A. R. (2000). Emotion, decision making and the orbitofrontal cortex. Cerebral cortex 10(3), 295-307. https://doi.org/10.1093/cercor/10.3.295

Bialik, K., \& Matsa, K. E. (2017). Key trends in social and digital news media. Retrieved from http://www.pewresearch.org/fact-tank/2017/10/04/key-trends-in-social-and-digital-newsmedia/

Bickart, B., Fournier, S. \& Nisenholtz, M. (2017). What Trump understands about using social media to drive attention. Harvard Business Review.

Benstead, L. J. (2013). Effects of interviewer-respondent gender interaction on attitudes toward women and politics: Findings from Morocco. International Journal of Public Opinion Research, 26(3), 369-383. https://doi.org/10.1093/ijpor/edt024

Brosch, T., Scherer, K. R., Grandjean, D. M. \& Sander, D. (2013). The impact of emotion on perception, attention, memory, and decision-making. Swiss medical weekly, 143, w13786. https://doi.org/10.4414/smw.2013.13786 
Negative Marketing in Political Campaigns and Its Effect on the Voting Decision of the ...

Button, K. S., loannidis, J. P., Mokrysz, C., Nosek, B. A., Flint, J., Robinson, E. S. \& Munafò, M. R. (2013). Power failure: why small sample size undermines the reliability of neuroscience. Nature Reviews Neuroscience, 14(5), 365. https://doi.org/10.1038/nrn3475

Center for Information and Research on Civic Learning and Engagement (2008). Retrieved from https://community-wealth.org/content/circle-center-information-and-research-civiclearning-and-engagement

Cook, I. A., Warren, C., Pajot, S. K., Schairer, D., and Leuchter, A. F. (2011). Regional brain activation with advertising images. Journal of Neuroscience, Psychology, and Economics, 4(3), 147.

Derbaix, C. M. (1995). The impact of affective reactions on attitudes toward the advertisement and the brand: A step toward ecological validity. Journal of Marketing Research, 32, 470-479. https://doi.org/10.2307/3152182

Dodou, D., \& de Winter, J. C. (2014). Social desirability is the same in offline, online, and paper surveys: A meta-analysis. Computers in Human Behavior, 36, 487-495. https://doi.org/10.1016/j.chb.2014.04.005

Hamelin, N., El Moujahid, O. \& Thaichon, P. (2017). Emotion and advertising effectiveness: A novel facial expression analysis approach. Journal of Retailing and Consumer Services, 36, 103-111. https://doi.org/10.1016/i.jretconser.2017.01.001

Harfoush, R. (2009). Yes We Did! An inside look at how social media built the Obama brand. New Riders.

Hentschke, H., \& Stüttgen, M. C. (2011). Computation of measures of effect size for neuroscience data sets. European Journal of Neuroscience, 34(12), 1887-1894. https://doi.org/10.1111/j.1460-9568.2011.07902.x

Hesseldahl, A., McMillan, D. \& Kharif , O. (2008) . The vote: A victory for social media: Too. BusinessWeek, November 5, p. 15.

Hopkins, R. \& Fletcher, J. E. (1994). Electrodermal measurement: Particularly effective for forecasting message influence on sales appeal. In A. Lang (Ed.), Measuring psychological responses to media messages (pp. 113-132). Hillsdale, NJ: Erlbaum.

Johnson-Cartee, K. S., \& Copeland, G. (2013). Negative political advertising: Coming of age. Routledge.

Kaid, L., Fernandes, J., \& Painter, D. (2011). Effects of political advertising in the 2008 presidential campaign. American Behavioral Scientist, 55(4), 437-456. https://doi.org/10.1177/0002764211398071

Kapoor, K. K., \& Dwivedi, Y. K. (2015). Metamorphosis of Indian electoral campaigns: Modi's social media experiment. International Journal of Indian Culture and Business Management, 11(4), 496-516.

Kirby, E. (2018). The city getting rich from fake news. [online] BBC News. Retrieved from https://www.bbc.com/news/magazine-38168281 [Accessed 2 Jul. 2018].

Lyons, M. N. (2017). Ctrl-Alt-Delete: The Origins and Ideology of the Alternative Right. Somerville, MA: Political Research Associates, January, 20.

Ohm, B. (2015). Organizing Popular Discourse with and against the Media: Notes on the Making of Narendra Modi and Recep Tayyip Erdoğan as Leaders-without-Alternative. Television \& New Media, 16(4), 370-377. https://doi.org/10.1177/1527476415575906 
Pal, J., Chandra, P. \& Vydiswaran, V. V. (2016). Twitter and the rebranding of Narendra Modi. Economic \& Political Weekly, 51(8), 52-60.

Poels, K. \& Dewitte, S. (2006). How to capture the heart? Reviewing 20 years of emotion measurement in advertising. Journal of Advertising Research, 46, 18-37. https://doi.org/10.2501/S0021849906060041

Rainie, H., Cornfield, M., \& Horrigan, J. B. (2005). The Internet and campaign 2004. Pew Internet \& American Life Project.

Qadri, M. \& Mufti, S. (2016). Films and Religion: An analysis of Aamir Khan's PK. Journal of Religion \& Film, 20(1), 9.

Ravaja, N. (2004). Contributions of psychophysiology to media research: Review and $\begin{array}{llll}\text { recommendations. Media 193-235. } & \text { 6sychology, }\end{array}$ https://doi.org/10.1207/s1532785xmep0602 4

Silverman, C. and Alexander, L. (2018). How Teens In The Balkans Are Duping Trump Supporters With Fake News. BuzzFeed. Retrieved from https://www.buzzfeed.com/craigsilverman/how-macedonia-became-a-global-hub-for-protrump-misinfo?utm_term=.vvPaVMbk4\#.yjXOMVNLw [Accessed 2 Jul. 2018].

Smith, A. (2009). The Internet's role in campaign 2008. PEW Internet and American life project. Retrieved from http://www.pewInternet.org/Reports/2009/6--The-Internets-Rolein-Campaign-2008.aspx

Smith, A. \& Banic, V. (2016) How Macedonian teens earn - and spend - thousands from fake news. (n.d.). Retrieved from https://www.nbcnews.com/news/world/fake-news-howpartying-macedonian-teen-earns-thousands-publishing-lies-n692451

Tedesco, J. C., \& Kaid, L. L. (2003). Style and effects of the Bush and Gore spots. In L. L. Kaid, J. C. Tedesco, D. G. Bystrom, \& M. S. McKinney (Eds.), The millennium election: Communication in the 2000 campaign (pp. 5-16). Lanham, MD: Rowman \& Littlefield.

Van Steenburg, E. (2015). Areas of research in political advertising: a review and research agenda. International journal of advertising, 34(2), 195-231.

Watts, D. J., Peretti, J. \& Frumin, M. (2007). Viral marketing for the real world. Harvard Business School Pub.

Yuksel, H., Civan, A., \& Gundogan, E. (2011). The Impact of Economic and Political Factors on the 2010 Turkish Referendum. Eurasian Journal of Business and Economics, 4 (7), 69-80.

Zhang, Y., Wells, C., Wang, S., \& Rohe, K. (2017). Attention and amplification in the hybrid media system: The composition and activity of Donald Trump's Twitter following during the 2016 presidential election. New Media \& Society, 1461444817744390.

https://doi.org/10.1177/1461444817744390 
Negative Marketing in Political Campaigns and Its Effect on the Voting Decision of the ...

\title{
Appendix
}

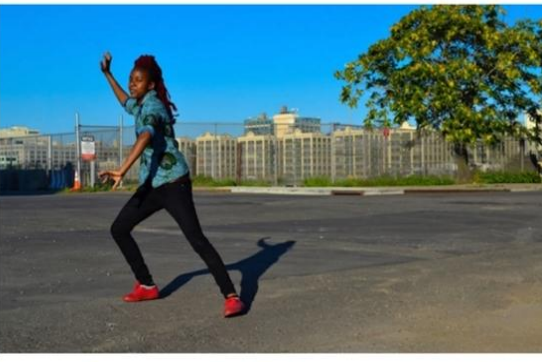

Lessons from one of Africa's youngest social entrepreneurs

LATEST STORIES

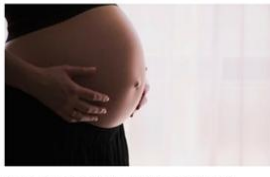

In a Landmark Judgment, SC Allows 26-Week Pregnant Woman to Abort Due to Fatal Health Conditions

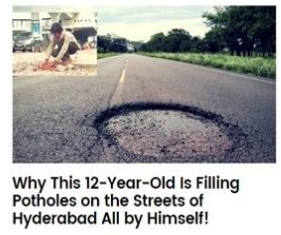

\section{Picture A1. Positive news slide}

Aam Aadmi Party @Simitator

Arvind Kejriwal lays the foundation for smart housing complex for NDMC employees

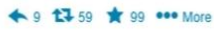

$1200 \mathrm{AM}-4 \mathrm{Jul} 17$ - Embed this Tweet

NDMC initiates building of smart housing complex for employees

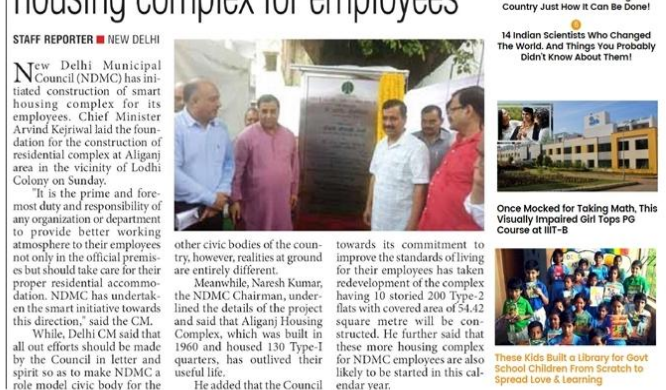

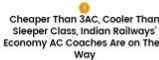
16 Famous Indians With Disabilite
Who Inspire Us Everyday 30000 30,000 Formers Are Ditching
Middlemen $\&$ selling Their Produce 12 unusual Weddings that will Waste-Free in Just 2 vears. This Tamil Nadu Town is Showing this
Country Just How It Con Be Done

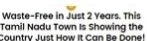
. lor
likecly to be se
endar year.

\begin{abstract}
Picture A1. Positive news slide
\end{abstract}

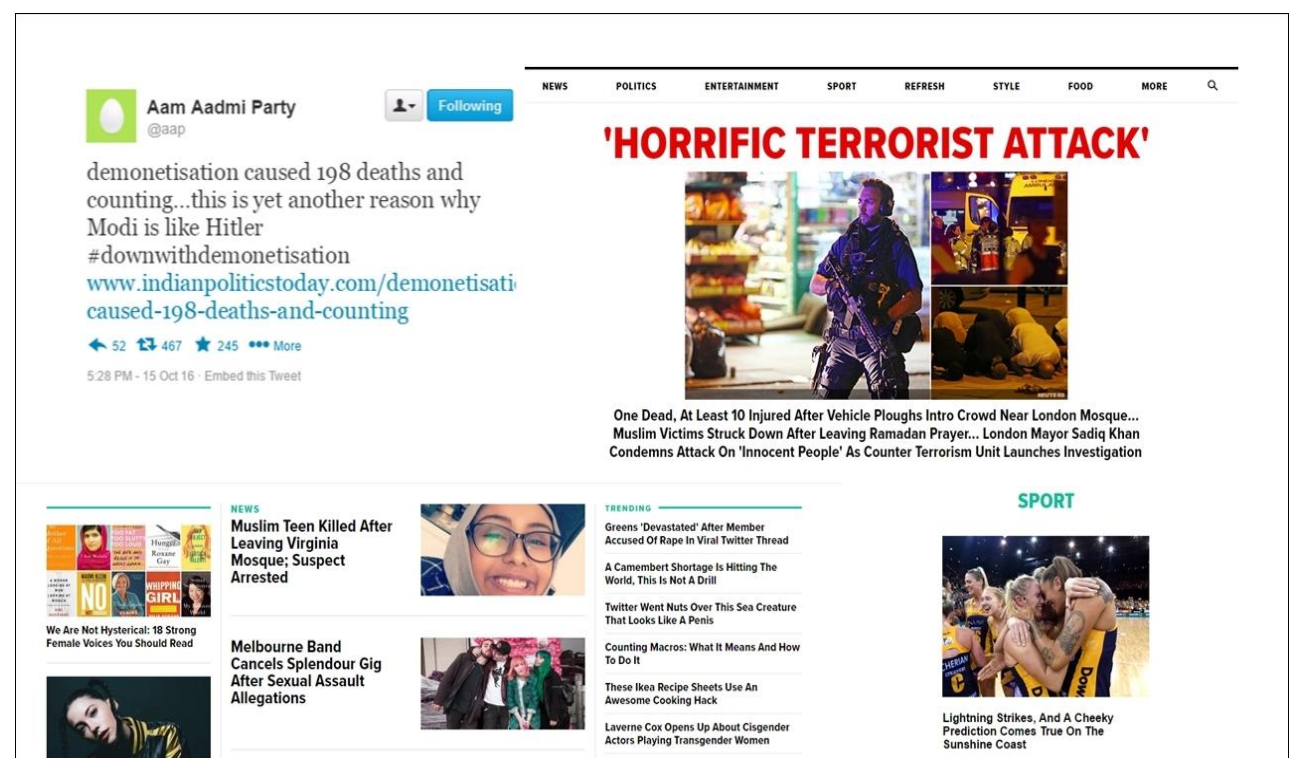

Picture A2. Negative news slide 